\title{
Salinity Risk and Management in Tunisian Semi Arid
}

\section{Area}

\author{
Mohamed Hachicha ${ }^{1}$, Sabri Kanzari ${ }^{1}$, Mohsen Mansour ${ }^{2}$, Omar Jouzdan ${ }^{3}$ and Awadis Arselan ${ }^{3}$ \\ 1. Laboratory of Valorization of non Conventional Water, National Institute of Rural Engineering, Waters and Forest, Ariana 2080, \\ Tunisia \\ 2. Regional Research Centre of Horticulture and Biological agriculture, Chott Merien, Sousse 4042, Tunisia \\ 3. Arab Centre of Studying Arid Lands and Dry Areas, Damascus 2440, Syria
}

Received: March 12, 2012 / Accepted: September 17, 2012 / Published: February 28, 2013.

\begin{abstract}
In semi arid and arid countries, the increase in production needs sometimes using brackish/saline water for irrigation. In Kairouan and Mahdia (Centre of Tunisia), most of the irrigated areas are by pumping ground water from wells and in many cases, water has more than $4 \mathrm{~g}$ of salt per liter. To improve farmers' income through using efficiently brackish/saline and rare water, applied research programme was carried out. The methodology adopted was based on selection of six farmers' parcels. Behind water quality and quantity, soil salinity and crop response, the crop cost was studied: initial and final characterization and frequently controlled. Three different water regimes were observed induced three salinity regimes: an exclusively irrigated regime in summer based on using saline water producing continuous accumulation of salts, an irrigated-rained regime in autumn/spring based on alternated saline and fresh water inducing cyclic accumulation and leaching of salts and a rained regime in winter based on fresh water with continuous leaching of salts. At the short term, soil salinity increased under irrigation until equilibrium with the irrigation water quality and decreased by rain which produced an important salts leaching in a very short time. Many tons of salts were added to the initial stock in summer season and most of them are leached to the subsoil under irrigation and by rain in the winter. Salinization affected the deep layer and on the long term, salinization of the aquifer might occur. An important crop yield decrease for the summer crop was obtained but the socio-economic aspect appeared as an important factor conditioning the use of saline water.
\end{abstract}

Key words: Soil, salinity, aquifer, crops, Central Tunisia.

\section{Introduction}

In semi arid and arid countries as Tunisia, irrigated areas are very important. The increase in production needs a good water quality and soil management because these resources are limiting factors for agriculture production. The use of saline water for irrigation is feasible, especially when saline water are blended or alternated with good quality [1]. This was what indirectly happened in cases where rainfalls were greater than $200 \mathrm{~mm}$ [2]. For long term, crop rotation must be used under this quantity of rainfall which was not enough to leach the salts. There are

Corresponding author: Mohamed Hachicha, Ph.D., research field: soil sciences. E-mail: hachicha8@gmail.com. many regions in the world where soils have been irrigated with saline waters successfully over many decades without degradation. In each instance, leaching and adequate drainage have been the factors that assure success [3-6]. There are also many cases of irrigation failure [7, 8]. In Kairouan and Mahdia (Centre of Tunisia), the irrigated areas represent about $20 \%$ of 400,000 hectares irrigated in Tunisia. Most of these areas are irrigated by ground water pumped from wells. In Many times, water has high salt concentration of more than $4 \mathrm{~g}$ of salt per litre (between $4.0 \mathrm{dS} / \mathrm{m}$ and $6.5 \mathrm{dS} / \mathrm{m}$ ). The over exploitation of ground water resources induces a decrease of the piezometric level of the groundwater and the degradation of its quality by saline water 
intrusion from the sea or sebkhats. In some regions, irrigation is a new practice and the farmers have not enough experiences to use water efficiently and to manage soil, water and plant under saline conditions. After some years, problems related to salinity were observed and decrease of crop yield was noticed. Moreover, there are not enough applied researches in the field of brackish/saline water to be transferred to the farmers in particular concerning the small-irrigated areas, which depend on ground water, wells in the Centre of Tunisia. According to that, applied research programme for the utilization of brackish/saline water was carried out from 2001 to 2005 (International Fund for Agricultural Development/Arab Center for the Study of Arid Zones and Dry Lands) and continue now through the "Transfer of the use of brackish and saline waters to the farmers" (National Institue of Rural Engeneering, Waters and Forest/Arab Center for the Study of Arid Zones and Dry Lands). The objective was to improve the production of irrigated systems through an adapted and efficient use of rare and saline water by the farmers. The main activities were [9]: transfer the adapted management methods to the farmers, develop local guideline and norms of irrigation by using saline water, add complementary and adapted researches to increase farmers' income and strength the institutional and human capacity building.

\section{Materials and Methods}

The general methodology used concerns the transfer of adapted management methods to the farmers and to add complementary and adapted new researches on saline water, soil salinity and crop management. According to that, six parcels were selected in the semi arid region of Mahdia and Kairouan (Centre of Tunisia) where the water quality used has more than $4 \mathrm{~g}$ of salt/liter ( $>6 \mathrm{dS} / \mathrm{m}$ ). These regions receive about $250 \mathrm{~mm}$ of rain per year with about $1,600 \mathrm{~mm}$ of ETP (evapotranspiration) for Bou Hajla and about $350 \mathrm{~mm}$ of rain per year with about 1,400 mm of ETP for Mahdia.

In Mahdia, soil texture between the surface and $1.5 \mathrm{~m}$ is loamy sand to sandy loam with about $80 \%$ of sand and less than $15 \%$ of clay. The available water is low less than $70 \mathrm{~mm}$ for $0-1 \mathrm{~m}$ of soil depth. The initial soil salinity ECe (electrical conductivity of the saturated soil extract) differs from farmer to farmer between $2 \mathrm{dS} / \mathrm{m}$ to $5 \mathrm{dS} / \mathrm{m}$. In Kairouan, soil texture between the surface and $1.5 \mathrm{~m}$ depth is sandier than Mahdia and the available water is lower. The initial soil salinity is between $1 \mathrm{dS} / \mathrm{m}$ to $5 \mathrm{dS} / \mathrm{m}$. Concerning the water quality, the ECw (electrical conductivity of water) is high between $5.4 \mathrm{dS} / \mathrm{m}$ and $7.0 \mathrm{dS} / \mathrm{m}$.

The experiments were carried out from 2002 to 2005. The main crops of the region were used in this study. Irrigation scheduling was done according the climate parameters and water requirement of the crop and the computer programme CROPWAT [10] modified by ACSAD [11].

The salinization risks are analyzed through the water and salt balances. Soil and irrigation water for each parcels were characterized and periodically measured, soil and water samples were taken and chemical analyses were carried out. Average between soil surface and $1 \mathrm{~m}$ depth of the electrical conductivity of the ECe (Electrical conductivity of saturated soil extract) was used. During crop cycle, water quantity was controlled. For the long term, hydrus-1d model [12] was used after calibration to estimate the deep water percolation and salt transfer.

For the salinity management, the following factors were included: water quality (ECw: electrical conductivity of water), soil salinity, crop response, and crop cost which is generally missed. Crop response was measured for each parcel and crop. The crop cost was deduced directly for any realized expense and indirectly for the family work which is estimated from the activity, number of person, number of hours and normal salary of the job. 


\section{Results and Discussion}

\subsection{Saline Water Management}

In Table 1, some examples of crops and water used according to the season were presented. Total water supply varies between the region and the farmers. It is higher in Kairouan than Mahdia, coastal region. In general, three different water regimes can be distinguished. They induced three salt regimes:

- Exclusively irrigated regime based on the use of saline water for summer crops and greenhouses. This water regime produces a continuously accumulation of salts, an additive salt regime. Concerning the crops, saline water is the only irrigation water;

- Irrigated-rained regime based on use of alternated saline/fresh water for autumn/spring crops. This water regime produces a cyclic accumulation and leaching of salts, an additive-subtractive salts regime. In some cases, the accumulation is higher than the leaching and in other cases, the opposite according the rain regime was observed. Concerning the crops, rain contributes depending on the year, for a part to their water requirement. The saline water is a complement of irrigation. Three irrigations were by fresh water.
This alternated saline water use is a form of saline water use strategy;

- Rained regime based on the use of fresh water for winter crops. This water regime produces a continuously leaching of salts, a subtractive salts regime.

\subsection{Soil Salinity Variation}

Soil salinity variation appears on two terms: short and long.

- At the short term: The soil salinity increases under irrigation until the equilibrium with the irrigation water at about $6 \mathrm{dS} / \mathrm{m}$ and decreases by rain which produces an important salts leaching of the sandy soils in a very short time (about $6 \mathrm{~h}$ for $40 \mathrm{~mm}$ ). The winter-autumn crops are affected by the salinity during the first crop stage due to the residual salts of the previous crop. All the salts added by irrigation and a big quantity of salts initially present in the soil are leached by rain. Tons of salts are added to the initial stock. For about $5 \mathrm{dS} / \mathrm{m}$ of the soil salinity between $0 \mathrm{~m}$ and $1 \mathrm{~m}$ depth and average bulk density $1.5 \mathrm{~g} / \mathrm{cm}^{3}$, about 1.4 tons of salts are accumulated between soil surface and $1 \mathrm{~m}$ soil depth (Table 2). In summer season, more than $97 \%$ of salt imported by irrigation water

Table 1 Examples of the water used for some crops (in $\mathbf{~ m m}$; range for three parcels per region).

\begin{tabular}{|c|c|c|c|c|}
\hline \multirow{3}{*}{ Crop/Season/Year } & \multicolumn{4}{|c|}{ Region } \\
\hline & \multicolumn{2}{|c|}{ Mahdia } & \multicolumn{2}{|c|}{ Bou Hajla } \\
\hline & Saline water (irrigation) & Fresh water (Rain) & Saline water (irrigation) & Fresh water (Rain) \\
\hline Pepper-Field-Summer 2002 & $575-733$ & 28 & $824-1189$ & 0 \\
\hline Pepper-Greenhouse-Winter 2003 & $396-750$ & 0 & & \\
\hline Potato-Field-Autumn 2003 & $24-75$ & 322 & $138-271$ & 110 \\
\hline Barley-Field-Winter 2003 & & & $88-539$ & 149 \\
\hline Barley-Field-Winter 2004 & 54 & 97 & $120-183$ & 45 \\
\hline
\end{tabular}

Table 2 Examples of salt balance for a parcel in Bou Hajla region.

\begin{tabular}{|c|c|c|}
\hline & \multicolumn{2}{|c|}{ Crop per season } \\
\hline & Pepper Summer 02 & Barley Winter 03 \\
\hline ECw $(\mathrm{dS} / \mathrm{m})$ & 6.1 & 7.6 \\
\hline TDS (g/L) & 5.4 & 5.3 \\
\hline ECe-initial (0-1 m) & 5.7 & 5.0 \\
\hline ECe-final (0-1 m) & 10.2 & 3.0 \\
\hline Irrigation water (m³/ha) & 7,333 & 880 \\
\hline Imported salt by irrigation (T/ha) & 41.1 & 3.5 \\
\hline Soil salt balance (T/ha) & 1.4 & -0.63 \\
\hline Salt exported under $1 \mathrm{~m}$ depth (T/ha) & 39.7 & 4.1 \\
\hline (Salt imported by water-Salt in the soil) (\%) & 97 & 118 \\
\hline
\end{tabular}


goes under the arable layer. In winter season, the reduced quantity of salts imported by irrigation and salts accumulated in summer were leached progressively to the subsoil. At the arable layer (0-1 m depth), soil salinity increases with irrigation and decreases by rains;

- At the long term: Major part of salts is leached to deep layers by irrigation and rain. Salinization affects the deep layer and on the long term, salinization of the aquifer may occur.

In previous study, a prediction of long-term salts transfer was carried out by Hydrus-1D [12] in Bou Hajla parcel of [13]. Model calibration was performed on a flood irrigation experiment for 10 days to $4 \mathrm{~m}$ depth. The hydrodynamic parameters were determined by inverse modeling. Model validation was performed successfully during 577th days. The long-term evolution of the salinity profile in 20 years showed a cyclical salts leaching in the topsoil, the permanent accumulation of salts in around $2 \mathrm{~m}$ depth and a continuous leaching in the deeper layers (around $4 \mathrm{~m}$ ), which may increase groundwater contamination salinization risk.

\subsection{Crops Response and Cost}

Table 3 summarizes the main yield, yield decrease according the local maximum yield and the W.U.E (water use efficiency). It shows a significant yield decrease for the summer crop which exceeds $50 \%$ and reaches sometimes $75 \%$. According to Ayers and Westcot [14], the yield decrease must not exceed 50\% for an economical use of saline water. In spite, farmers continue to irrigate with this water. In the following crops cost paragraph. For the winter and autumn crops, the yield decrease is much lower and did not exceeds $50 \%$ in Mahdia area. This is induced by the importance of rain in the crop water requirement. The second aspect concerns the WUE. In spite of the yield decrease of potato is high and for barley and pepper is less, the WUE is double and more for this alternate crop.

The most utilized yield functions related to salinity of irrigation water are that proposed by Ayers and Wescott [14] on the basis of Maas and Hoffmann [15] model in the form $Y=100-b(E C e-a)$ where $Y=$ relative crop yield in percent, $E C e=$ salinity of the soil saturation extract in $\mathrm{dS} / \mathrm{m}, a=$ salinity threshold

Table 3 Summary of the range of yield, yield decrease and W.U.E. for each crop per season, year and region.

\begin{tabular}{|c|c|c|c|}
\hline \multirow{2}{*}{ Crop/Season/Year } & \multirow{2}{*}{ Parameter } & \multicolumn{2}{|c|}{ Region } \\
\hline & & Mahdia & Bou Hajla \\
\hline \multirow[t]{3}{*}{ Pepper-Field-Summer 2002} & Yield (T/ha) & $13.6-28.4$ & $7.1-12.3$ \\
\hline & Yield decrease (\%; $\left.\mathrm{Y}_{\max }=34 \mathrm{~T} / \mathrm{ha}\right)$ & $16-60$ & $64-79$ \\
\hline & W.U.E $\left(\mathrm{Kg} / \mathrm{m}^{3}\right)$ & $1.9-4.4$ & $0.6-1.4$ \\
\hline \multirow[t]{3}{*}{ Pepper-Greenhouse-Winter 2003} & Yield (T/ha) & $22.1-77.7$ & \\
\hline & Yield decrease (\%; $\left.\mathrm{Y}_{\max }=100 \mathrm{~T} / \mathrm{ha}\right)$ & 22.3-77.9 & \\
\hline & W.U.E $\left(\mathrm{Kg} / \mathrm{m}^{3}\right)$ & 2.4-8.0 & \\
\hline \multirow[t]{3}{*}{ Potato-Field-Autumn 2003} & Yield (T/ha) & $20.5-26.8$ & $5.9-12.0$ \\
\hline & Yield decrease (\%; $\left.\mathrm{Y}_{\max }=40 \mathrm{~T} / \mathrm{ha}\right)$ & $33-49$ & $70-85$ \\
\hline & W.U.E $\left(\mathrm{Kg} / \mathrm{m}^{3}\right)$ & $5.2-7.7$ & $2.0-4.4$ \\
\hline \multirow[t]{3}{*}{ Barley-Field-Winter 2003} & Yield (T/ha) & & $2.8-4.7$ \\
\hline & Yield decrease $\left(\% ; Y_{\max }=6\right.$ T/ha) & & $22-58$ \\
\hline & W.U.E $\left(\mathrm{Kg} / \mathrm{m}^{3}\right)$ & & $0.6-1.6$ \\
\hline \multirow[t]{3}{*}{ Barley-Field-Winter 2004} & Yield (T/ha) & $1.5-1.7$ & $3.0-4.3$ \\
\hline & Yield decrease (\%; $\left.Y_{\max }=6 \mathrm{~T} / \mathrm{ha}\right)$ & $72-75$ & $28-51$ \\
\hline & W.U.E $\left(\mathrm{Kg} / \mathrm{m}^{3}\right)$ & 1.1 & $1.3-2.2$ \\
\hline
\end{tabular}


Table 4 Summary of the crops costs by region, crop and season (min. and max.; in US \$).

\begin{tabular}{llcc}
\hline \multirow{2}{*}{ Crop/Season/Year } & Parameter & \multicolumn{2}{c}{ Region } \\
\cline { 3 - 3 } Pepper-Field-Summer 2002 & Total income (ha) & Mahdia & Bou Hajla \\
& Total cost (ha) & $325-662$ & \\
& Family work (\%) & $23-30$ & \\
Pepper-Greenhouse-Winter 2003 & Total income (ha) & $10,937-40,692$ & \\
& Total cost (ha) & $14,402-20,483$ & $2466-1248$ \\
Barley-Field-Winter 2003 & Family work (\%) & & $295-570$ \\
& Total income (ha) & & $24-33$ \\
\hline
\end{tabular}

value in $\mathrm{dS} / \mathrm{m}$ and $b=$ yield loss per unit increase in salinity. This equation expresses the straight line salinity effect on yield and indicates that plant growth rate decreases linearly as salinity increase above a critical salinity threshold at which growth rate first begins to decrease. In Tunisia, researchers are considering the US salinity laboratory norms and criteria for water use in irrigation [16]. They did not adapted specific norms for Tunisian conditions. Research in saline water use in agriculture was conducted in many experimental stations at the field condition. Yield functions are obtained for many crops for the lower Mejerda Valley in the north where annual average rainfall is about $450 \mathrm{~mm}$. For the more arid Tunisian region (Rainfall between $150 \mathrm{~mm}$ and $350 \mathrm{~mm}$ ) there are not any yield functions. Concerning the yield of pepper, Table 4 shows yield decrease according to water salinity. The main remark is the big difference between Kairouan and Mahdia farmers. When the maximum yield in Tunisia is 34 tons/ha obtained in Cherfech Station [17] under furrow irrigation, then the yield decrease is between $17 \%$ and $72 \%$ in Mahdia and between $64 \%$ and $79 \%$ in Kairouan.

\subsection{Crops Cost}

The socio-economic aspect is certainly an important factor conditioning the use of saline water. It is not studied as the technical factors such as crop salinity tolerance, soil salinity and irrigation techniques. According to Table 4, the cost of the family work represents about one third to quarter the total cost.
Family work means the activities done by the farmer, his wife and children. With high ECw, the income is normally low and not enough to cover the production cost. In this case, irrigation with saline water is marginal. Crop quality is also as important as crop yield. With saline water, the crop quality is frequently affected. Net income appears economic in familial agriculture scale practiced around shallow wells at a small area. It is a flexible system more adapted to the market criteria. Irrigation with saline water is economically efficient only on familial agriculture scale. This form of irrigated agriculture is usually practiced around shallow wells and on small areas. At large irrigated areas and without familial work or State support, saline water is not recommended for irrigation. This dimension must be considering on the use of saline water in agriculture and it is a form of salinity management.

\section{Conclusion}

Results show the feasibility of using saline ground water for irrigation in semi-arid region. Saline water could be used for small areas. Many aspects are observed. For saline water management, the water use efficiency indicates the necessity to improve irrigation management. Concerning soil salinity evolution and salinity risks, soil salinity increases under irrigation until the equilibrium with the irrigation water at about $6 \mathrm{dS} / \mathrm{m}$. Tons of salts are added to the initial soil salinity but a big quantity is leached to deep layers. On the short term, soil salinity increases with 
irrigation and decreases by rains. On the long term, salinization of the aquifer may occur and also in low lands are expected and salinity control of these parts of landscape must be studied. For the crop responses, high yield decrease is observed, variable between regions and farmers and also parcels. This decrease is higher for the summer crops and greenhouse crops than the winter crops. Finally, global approach is necessary to improve the saline water management included the socio-economical dimension. More studies and complementary actions must be taken in particular to improve water management by the farmers.

\section{References}

[1] J.D. Rhoades, Use of saline water for irrigation, Water Quality Bulletin 12 (1987) 12-21.

[2] J. Abdelgawad, The use of highly saline water for irrigation, Desertification Bulletin 26 (1995) 32-39.

[3] J.D. Rhoades, J. Loveday, Salinity in irrigated agriculture. Irrigation of agricultural crops, Agronomy Monograph 30 (1990) 1089-1142.

[4] J. Rhoades, A. Kandiah, M. Mashali, The use of saline waters for crop production, FAO Rome, 1992, pp.32-45.

[5] J. Oster, I. Shainberg, A. Abrol, Reclamation of salt-affected soil. Ch. 14. In: M. Agassi (Ed.), Soil Erosion, Conservation and Rehabilitation, Marcel Dekker, Inc. New York, 1996, pp. 315-351.

[6] M. Hachicha, C. Cheverry, A. Mhiri, The impact of long-term irrigation on changes of ground water level and soil salinity in northern Tunisia, Arid Soil Research and Rehabilitation 14 (2000) 175-182.

[7] I. Szabolcs, Prospects of soil salinity for the 21st century, 15th World Congress of Soil Science, Acapulco (Mexico),
International Soil Sciences Union, Volume 1: Inaugural state of the art conferences, 1994, pp. 123-141.

[8] E. Bresler, B.L. Mc Neal, D.L. Carter, Saline and sodics soils. Advanced series in agricultural series; Springer-Verlag Edition, 1982, pp. 133-139.

[9] IFAD, Applied research programme for the utilization of brackish/saline water in North Africa-Project document, 2000, pp. 1-19.

[10] R.G. Allen, L.S. Pereira, D. Raes and M. Smith, Crop evapotranspiration-Guidelines for computing crop water requirements, FAO Irrigation and Drainage Paper 56 (1998) 297.

[11] A. Gaibeh, J. Abdelgawed, A. Arselan, Computer programme for irrigation scheduling with saline water, Arab Centre of Studying Arid Lans and Dry Areas, 2002.

[12] J. Simunek, M. Sejna, M.T. Van Genuchten, The HYDRUS-1D software package for simulating the one-dimensional movement of water, heat, and multiple solutes in variably-saturated media: version 4.0, International Ground Water Modeling Center, Colorado School of Mines, Golden, 2008, pp. 1-315.

[13] S. Kanzari, M. Hachicha, R. Bouhlila, J. Battle-Sales, Simulation of water and salts dynamics in bouhajla (Central Tunisia): Exceptional rainfall effect, Soil and Water Research 7 (2012) 19-27.

[14] R.S. Ayers, D.W. Westcot, Water quality for agriculture, FAO Irrigation and Drainage, Paper 29.1 revised, FAO, Rome, Italy, 1985.

[15] E.V. Maas, G.J. Hoffman, Crop salt tolerance, current assessment, J. Irrig. Drain. Div. American Society of Civil Engineering 103 (1977) 115-134.

[16] L.A. Richards, Diagnosis and Improvement of Saline and Alkali Soils, Agriculture Handbook No. 60, US Department of Agriculture, Washington, DC, 1954.

[17] CRUESI, Research and training on irrigation with saline water, Technical report/UNESCO/UNDP TUN. 5, Paris, France, 1970. 